Check for updates

Cite this: RSC Adv., 2017, 7, 24718

Received 27th February 2017 Accepted 27th April 2017

DOI: $10.1039 / \mathrm{c7ra02446k}$

rsc.li/rsc-advances

\section{Penicimutamides D-E: two new prenylated indole alkaloids from a mutant of the marine-derived Penicillium purpurogenum G59†}

\author{
Chang-Jing Wu, ab Chang-Wei Li, (D) *a Hao Gao, ${ }^{c}$ Xiao-Jun Huang ${ }^{c}$ \\ and Cheng-Bin $\mathrm{Cui}^{\mathrm{a}}$
}

Three prenylated indole alkaloids (1-3), including two new penicimutamides D-E (1-2), were isolated from a diethyl sulfate mutant of the marine-derived fungus Penicillium purpurogenum G59. The structures of 13 , and their absolute configurations, were determined by spectroscopic methods, including $\mathrm{X}$-ray crystallography and CD analyses. HPLC-UV and HPLC-MS analyses showing that 1-3 were only produced in the mutant evidenced that the silent biosynthetic pathways that produce 1-3 in the parental strain are activated by DES mutagenesis.
Prenylated indole alkaloids (PIAs) are a broad class of secondary fungal metabolites with a bicyclo[2.2.2]diazaoctane core ring system. ${ }^{1}$ Included in this group are brevianamides, ${ }^{2}$ notoamides, ${ }^{3}$ stephacidins, ${ }^{4}$ versicolamides, ${ }^{5}$ paraherquamides, ${ }^{6}$ malbrancheamides ${ }^{7}$ and marcfortines. ${ }^{8}$ Total syntheses, ${ }^{9}$ biomimetic syntheses ${ }^{10}$ and biosyntheses ${ }^{11}$ of PIAs, focusing on formation of the core ring system, have been extensively investigated because of the interesting structures of the PIAs.

In our previous work, ${ }^{12}$ three rare carbamate-containing PIAs, penicimutamides A-C, were isolated from a fungal mutant $\mathrm{AD}-2$ 1 of a marine-derived Penicillium purpurogenum G59 via diethyl sulfate (DES) mutagenesis. As a continuation of this, we herein report on three other PIAs, including two new penicimutamides D-E (1-2 in Fig. 1) and a known one (3). These compounds were produced in the same solid culture by the mutant AD-2-1 by activating silent pathways in parent G59 strain. The mutant AD-21 was selected by treating Penicillium purpurogenum G59 spores with $1 \%(\mathrm{v} / \mathrm{v})$ DES in $50 \%(\mathrm{v} / \mathrm{v})$ DMSO at $4{ }^{\circ} \mathrm{C}$ for $1 \mathrm{~d}$. This produced a series of novel lipopeptides in liquid culture via the activation of pathways that were silent in the G59 strain. ${ }^{13}$

To obtain new fungal secondary metabolites, the one-strainmany-compounds approach, ${ }^{14}$ chemical epigenetics ${ }^{15}$ and co-

${ }^{a}$ State Key Laboratory of Toxicology and Medical Countermeasures, Beijing Institute of Pharmacology and Toxicology, Beijing 100850, China. E-mail: sdrlcw@126.com; Fax: +86-10-68211656; Tel: +86-10-68211656

${ }^{b}$ College of Life Science and Agronomy, Zhoukou Normal University, Zhoukou 466001, China

'Institute of Traditional Chinese Medicine \& Natural Products, College of Pharmacy, Jinan University, Guangzhou 510632, China

$\dagger$ Electronic supplementary information (ESI) available: Experimental procedures, NMR data for 1-3, DFT-optimized structures of the low-energy conformers for 1 and 2, figures for the HPLC-UV and HPLC-MS analyses, various spectra for 1-3, and X-ray data of 1 (CIF file). CCDC 1532020. For ESI and crystallographic data in CIF or other electronic format see DOI: $10.1039 / \mathrm{c} 7 \mathrm{ra02446 \textrm {k }}$ cultivation ${ }^{16}$ have been used to activate silent pathways by varying environmental factors for growth of the producing strains. In our previous work, ${ }^{17}$ a series of new methods ${ }^{17 a-c}$ based on ribosome engineering ${ }^{18}$ were developed for fungi, and several new secondary metabolites were isolated from the mutants. ${ }^{17 c-e}$ During this study, a practical mutagenesis strategy using DES was developed to activate silent fungal pathways. ${ }^{13,19}$ A diverse range of secondary metabolites were isolated from the DES mutant of Penicillium purpurogenum G59 by activating pathways that were silent in the parent strain via DES mutagenisis. ${ }^{19 a}$

As reported in our previous work, the mutant AD-2-1 and parental G59 strains were fermented concurrently under the same conditions at $28^{\circ} \mathrm{C}$ for $50 \mathrm{~d}$ using rice as a solid substrate fermentation medium to obtain methanol $(\mathrm{MeOH})$ extracts of their cultures. These cultures inhibited K562 cells with inhibition rates of $62.5 \%$ and $6.1 \%$ at $100 \mu \mathrm{g} \mathrm{mL} \mathrm{m}^{-1}$, respectively. Production of new metabolites was tracked to guide separation of the mutant extract, and resulted in the isolation of 1-3 (Table 1).

After analysis by HR-ESI-MS, penicimutamide D (1) was assigned the molecular formula $\mathrm{C}_{21} \mathrm{H}_{25} \mathrm{~N}_{3} \mathrm{O}_{2}(\mathrm{~m} / z 352.2025[\mathrm{M}+$

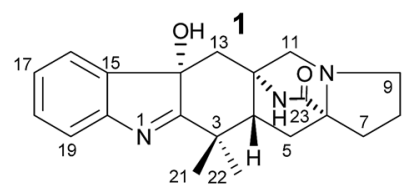

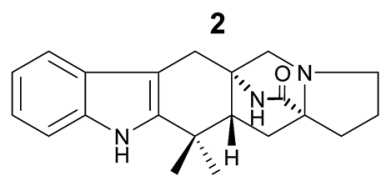

1: penicimutamide $D$ 2: penicimutamide $\mathrm{E}$ 3: ( \pm )-premalbrancheamide

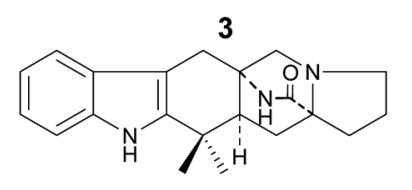

Fig. 1 Structures of compounds $1-3$. 
Table $1600 \mathrm{MHz}^{1} \mathrm{H}$ and $150 \mathrm{MHz}{ }^{13} \mathrm{C} \mathrm{NMR}$ data for $1-3$ in $\mathrm{CD}_{3} \mathrm{OD}^{a}$

\begin{tabular}{|c|c|c|c|c|c|c|c|c|c|}
\hline \multirow[b]{2}{*}{ No. } & & \multicolumn{2}{|l|}{1} & & \multicolumn{2}{|l|}{2} & & \multicolumn{2}{|l|}{3} \\
\hline & & $\delta_{\mathrm{H}}(\mathrm{J}$ in $\mathrm{Hz})$ & $\delta_{\mathrm{C}}^{b}$ & & $\delta_{\mathrm{H}}(\mathrm{J}$ in $\mathrm{Hz})$ & $\delta_{\mathrm{C}}^{b}$ & & $\delta_{\mathrm{H}}(\mathrm{J}$ in $\mathrm{Hz})$ & $\delta_{\mathrm{C}}^{b}$ \\
\hline 3 & & - & $41.6 \mathrm{~s}$ & & - & $29.1 \mathrm{~s}$ & & - & $35.4 \mathrm{~s}$ \\
\hline 4 & & 2.00 dd $(9.0,5.4)$ & $51.6 \mathrm{~d}$ & & $2.19 \mathrm{dd}(10.1,3.7)$ & $47.6 \mathrm{~d}$ & & $2.00 \mathrm{dd}(10.8,5.4)$ & $48.5 \mathrm{~d}$ \\
\hline 5 & $\mathrm{H} \beta$ & 2.10 dd $(12.6,9.0)$ & $32.9 \mathrm{t}$ & $\mathrm{H} \beta$ & $2.14 \mathrm{dd}(13.4,10.1)$ & $31.9 \mathrm{t}$ & $\mathrm{H} \alpha$ & $1.99 \mathrm{dd}(13.2,10.8)$ & $32.5 \mathrm{t}$ \\
\hline \multirow[t]{2}{*}{7} & $\mathrm{H} \alpha$ & $2.57 \mathrm{dt}(12.6,6.6)$ & $28.1 \mathrm{t}$ & $\mathrm{H} \alpha$ & 2.52 ddd $(12.6,9.0,4.8)$ & $28.09 \mathrm{t}$ & $\mathrm{H} \alpha$ & $2.51 \mathrm{ddd}(13.2,9.0,6.0)$ & $28.2 \mathrm{t}$ \\
\hline & $\mathrm{H} \beta$ & $1.47 \operatorname{td}(12.6,7.8)$ & & $\mathrm{H} \beta$ & 1.47 ddd $(12.6,10.8,7.2)$ & & $\mathrm{H} \beta$ & $1.44 \mathrm{ddd}(13.2,10.8,7.2)$ & \\
\hline 8 & & $1.95-1.892 \mathrm{H}, \mathrm{m}$ & $23.4 \mathrm{t}$ & & $1.96-1.892 \mathrm{H}, \mathrm{m}$ & $23.4 \mathrm{t}$ & & $1.89-1.822 \mathrm{H}, \mathrm{m}$ & $23.6 \mathrm{t}$ \\
\hline \multirow[t]{2}{*}{9} & $\mathrm{H} \alpha$ & $3.10 \mathrm{dt}(9.0,5.4)$ & $54.7 \mathrm{t}$ & $\mathrm{H} \beta$ & $3.115 \operatorname{td}(9.0,4.2)$ & $54.3 \mathrm{t}$ & $\mathrm{H} \beta$ & 3.04 ddd $(9.0,7.2,3.6)$ & $55.4 \mathrm{t}$ \\
\hline & $\mathrm{H} \beta$ & $2.31 \mathrm{q}(9.0)$ & & $\mathrm{H} \alpha$ & $2.39 \mathrm{q}(9.0)$ & & $\mathrm{H} \alpha$ & 2.15 br q $(9.0)$ & \\
\hline 11 & $\mathrm{H} \beta$ & $2.89 \mathrm{~d}(10.2)$ & $62.4 \mathrm{t}$ & $\mathrm{H} \beta$ & $3.110 \mathrm{~d}(10.2)$ & $62.4 \mathrm{t}$ & $\mathrm{H} \beta$ & $3.45 \mathrm{~d}(10.2)$ & $59.5 \mathrm{t}$ \\
\hline 14 & & - & $83.7 \mathrm{~s}$ & & - & $103.7 \mathrm{~s}$ & & - & $104.5 \mathrm{~s}$ \\
\hline 15 & & - & $143.0 \mathrm{~s}$ & & - & $128.4 \mathrm{~s}$ & & - & $128.2 \mathrm{~s}$ \\
\hline 16 & & 7.45 br d (7.8) & $123.3 \mathrm{~d}$ & & 7.38 br d $(7.7)$ & $118.5 \mathrm{~d}$ & & $7.33 \mathrm{br} \mathrm{d}(8.0)$ & $118.3 \mathrm{~d}$ \\
\hline 17 & & $7.26 \operatorname{td}(7.8,0.8)$ & $127.6 \mathrm{~d}$ & & 6.96 ddd $(7.7,7.1,0.8)$ & $119.5 \mathrm{~d}$ & & 6.93 td $(8.0,0.9)$ & $119.5 \mathrm{~d}$ \\
\hline 18 & & $7.37 \operatorname{td}(7.8,1.2)$ & $130.6 \mathrm{~d}$ & & 7.04 ddd $(8.1,7.1,1.2)$ & $122.0 \mathrm{~d}$ & & $7.02 \operatorname{td}(8.0,1.1)$ & $122.0 \mathrm{~d}$ \\
\hline 19 & & $7.48 \mathrm{br} \mathrm{d}(7.8)$ & $121.2 \mathrm{~d}$ & & 7.27 br d (8.1) & $111.7 \mathrm{~d}$ & & 7.25 br d $(8.0)$ & $111.6 \mathrm{~d}$ \\
\hline 20 & & - & $152.9 \mathrm{~s}$ & & - & $138.4 \mathrm{~s}$ & & - & $138.5 \mathrm{~s}$ \\
\hline 21 & & $1.303 \mathrm{H}, \mathrm{s}$ & $26.9 \mathrm{q}$ & & $1.313 \mathrm{H}, \mathrm{s}$ & $28.06 \mathrm{q}$ & & $1.423 \mathrm{H}, \mathrm{s}$ & $24.4 \mathrm{q}$ \\
\hline 22 & & $1.413 \mathrm{H}, \mathrm{s}$ & $19.9 \mathrm{q}$ & & $1.203 \mathrm{H}, \mathrm{s}$ & $24.6 \mathrm{q}$ & & $1.323 \mathrm{H}, \mathrm{s}$ & $30.9 \mathrm{q}$ \\
\hline 23 & & - & $175.2 \mathrm{~s}$ & & - & $175.9 \mathrm{~s}$ & & - & $176.8 \mathrm{~s}$ \\
\hline
\end{tabular}

${ }^{a}$ Chemical shift $\left(\delta_{\mathrm{H}}\right.$ and $\left.\delta_{\mathrm{C}}\right)$ were recorded using the solvent signals of $\mathrm{CD}_{3} \mathrm{OD}\left(\delta_{\mathrm{H}} 3.31 / \delta_{\mathrm{C}} 49.00\right)$ as references. Signals assignments were based on the results of DEPT, ${ }^{1} \mathrm{H}-{ }^{1} \mathrm{H}$ COSY, HMQC and HMBC experiments. ${ }^{b}$ Multiplicities of the carbon signals were determined by DEPT experiments and are indicated by s (singlet), d (doublet), t (triplet) and q (quartet).

$\mathrm{H}]^{+}$, calcd for $\mathrm{C}_{21} \mathrm{H}_{26} \mathrm{~N}_{3} \mathrm{O}_{2}$ 352.2025), which has one more oxygen atom than the known compound 3. UV absorptions at 220 and $264 \mathrm{~nm}$ showed it contained the indole structure. The ${ }^{1} \mathrm{H}$ NMR data for $\mathrm{H}-16(\delta 7.53$, br d, $J=7.8 \mathrm{~Hz}), \mathrm{H}-19(\delta 7.52$, br $\mathrm{d}, J=7.8 \mathrm{~Hz}), \mathrm{H}-18(\delta 7.46, \mathrm{td}, J=7.8,1.2 \mathrm{~Hz})$ and $\mathrm{H}-17(\delta 7.31$, $\mathrm{td}, J=7.8,1.2 \mathrm{~Hz}$ ) supported the presence of a disubstituted phenyl group in the indole structure. The ${ }^{1} \mathrm{H}$ NMR, HMQC and ${ }^{1} \mathrm{H}^{1}{ }^{1} \mathrm{H}$ COSY spectra showed five spin systems of $\mathrm{H}_{3}-21-\mathrm{C}-3-\mathrm{H}_{3}-$ $22,-\mathrm{H}_{2}-13-,-\mathrm{H}_{2}-11-,-\mathrm{H}-4-\mathrm{H}_{2}-5-$, and $-\mathrm{H}_{2}-7-\mathrm{H}_{2}-8-\mathrm{H}_{2}-9-$ (Fig. 2). All of the above spin systems were the same as those for the known compound $\mathbf{3}$, which suggested $\mathbf{1}$ had the same skeleton as $\mathbf{3}$. When the ${ }^{13} \mathrm{C}$ NMR spectrum of $\mathbf{1}$ was compared with that of 3 , the biggest differences were the absence of a $\mathrm{sp}^{2}$ carbon signal (C-14 of 3) and appearance of an oxygenated $\mathrm{sp}^{3}$
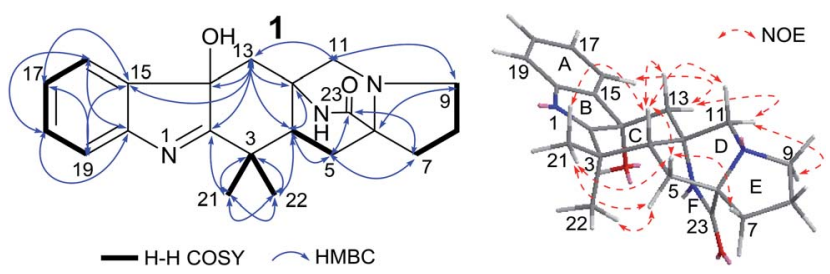

Fig. 2 Structures and key NMR data for 1. carbon signal (C-14 of $\mathbf{1})$. So, it could be deduced that $\mathbf{1}$ is an oxidative product of 3 with a hydroxyl group at C-14. In addition the double bond was transferred from $\mathrm{C}_{2}=\mathrm{C}_{14}$ to $\mathrm{C}_{1}=\mathrm{C}_{2}$, which resulted in a high-field shift of C-2 from $\delta_{\mathrm{C}} 142.2$ (in 3) to 192.6 (in 1). This gave a planar structure (Fig. 1), which was also supported by further NMR data (Fig. 2).

The NOEs observed in the NOESY of 1 between $\mathrm{H}-4 / \mathrm{H} \beta-11, \mathrm{H}-$ 4/H $\beta-13, \mathrm{H}-4 / \mathrm{H} \beta-5, \mathrm{H}-4 / \mathrm{H}_{3}-21$ and $\mathrm{H}_{3}-21 / \mathrm{H} \alpha, \beta-5$ indicated that ring $\mathrm{C}$ had a chair conformation and ring $\mathrm{D}$ had a boat conformation with $\mathrm{CH}_{3}-22, \mathrm{HO}-\mathrm{C}_{14}$ groups and the lactam group located on the same face. The NOEs between $\mathrm{H} \beta-5 / \mathrm{H} \beta-7$ and $H \alpha-9 / H \alpha-11$ showed that the $\mathrm{E}$ ring had an envelope conformation with $\mathrm{N}-10$ upwarped as shown in Fig. 2 . Thus, the relative configuration was established.

To determine the absolute configuration of 1, single-crystal X-ray diffraction using $\mathrm{Cu} \mathrm{K} \alpha$ radiation for $\mathbf{1}$ was performed. An ORTEP drawing of the crystallographically determined structure of $\mathbf{1}$ is depicted in Fig. 3. The relative configuration of 1 determined was in accordance with the result based on NOEs. But the Flack parameter was -0.2 (2), which was not perfect enough to determine the absolute configuration.

To confirm the absolute configuration of $\mathbf{1}$, TDDFT electronic CD (ECD) calculations $\mathrm{s}^{\mathbf{2 0 , 2 1}}$ for $\mathbf{1}$ and its enantiomer were performed. The calculated ECD of $\mathbf{1}$ agreed with the measured 


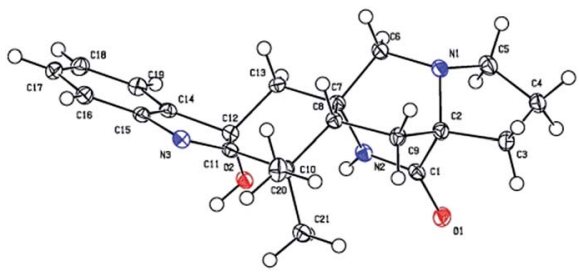

Fig. 3 The crystal structure of 1

CD data (Fig. 4), and showed that the absolute configuration was $4 R, 6 S, 12 S, 14 S$.

Penicimutamide E (2) was assigned the molecular formula $\mathrm{C}_{21} \mathrm{H}_{25} \mathrm{~N}_{3} \mathrm{O}_{1}$ by HR-ESI-MS $\left(\mathrm{m} / \mathrm{z} 336.2070[\mathrm{M}+\mathrm{H}]^{+}\right.$, calcd for $\mathrm{C}_{21} \mathrm{H}_{26} \mathrm{~N}_{3} \mathrm{O}_{2}$ 336.2072), which was the same as that of the known compound 3. The UV and IR spectra were also identical to those of 3. The similar ${ }^{1} \mathrm{H}$ and almost identical ${ }^{13} \mathrm{C}$ NMR data indicated that $\mathbf{2}$ had the same planar structure as $\mathbf{3}$, which was also supported by other NMR data.

The NOEs observed in the NOESY of 2 between $\mathrm{H}-4 / \mathrm{H} \beta-11, \mathrm{H}-$ $4 / \mathrm{H} \beta-13, \mathrm{H}-4 / \mathrm{H} \beta-5, \mathrm{H}-4 / \mathrm{H}_{3}-21, \mathrm{H}_{3}-21 / \mathrm{H} \alpha, \beta-5, \mathrm{H} \beta-5 / \mathrm{H} \beta-7$ and $\mathrm{H} \alpha-9 / \mathrm{H} \alpha-11$ established the relative configuration of 2 as shown in Fig. 5. To determine the absolute configuration of 2, TDDFT ECD calculations ${ }^{\mathbf{2 0 2}}$ for 2 and its enantiomer were performed. The calculated ECD of 2 agreed with the measured CD data (Fig. 6), and the absolute configuration of 2 was determined as $4 R, 6 S, 12 S$.

Compound 3 was obtained as a crystalline powder. The ${ }^{1} \mathrm{H}$ and ${ }^{13} \mathrm{C}$ NMR data were almost identical to the published data of (+)-premalbrancheamide, ${ }^{22}$ which indicated that 3 had the same planar structure as (+)-premalbrancheamide. The NOEs observed in the NOESY spectrum (Fig. 7) also indicated that 3 had the same relative stereochemistry as (+)-premalbrancheamide (Fig. 6). The $[\alpha]_{\mathrm{D}}$ of $3\left(+3.2^{\circ}\right)$ was smaller than that of $(+)$-premalbrancheamide $\left(+15^{\circ}\right),{ }^{23}$ and there was no Cotton effect
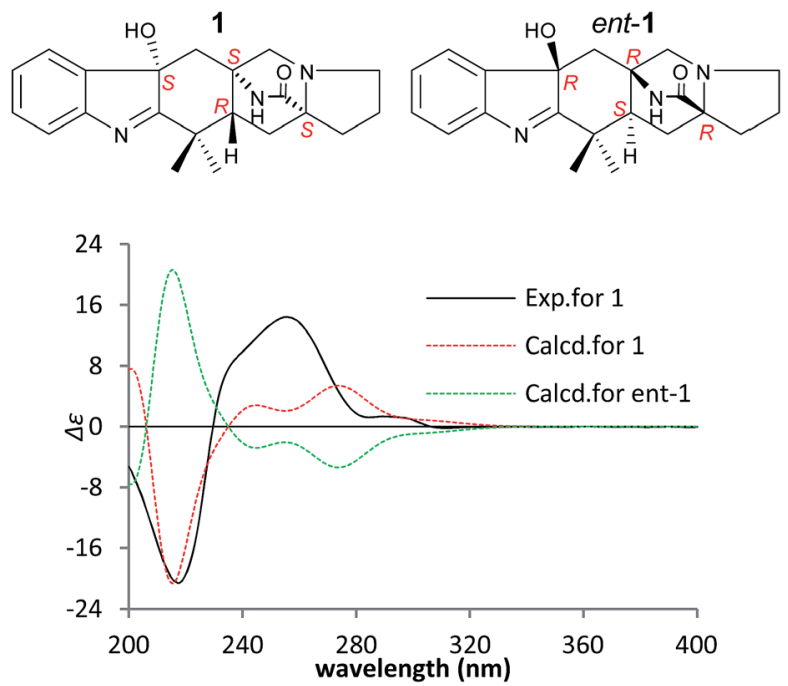

Fig. 4 Measured and calculated ECD spectra of 1 and its enantiomer in $\mathrm{MeOH}$.
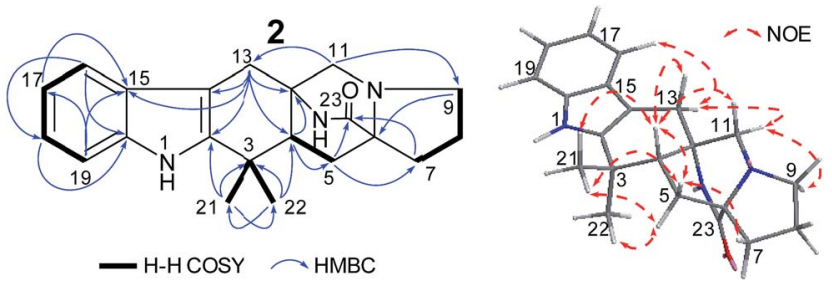

Fig. 5 Structures and key NMR data for 2.
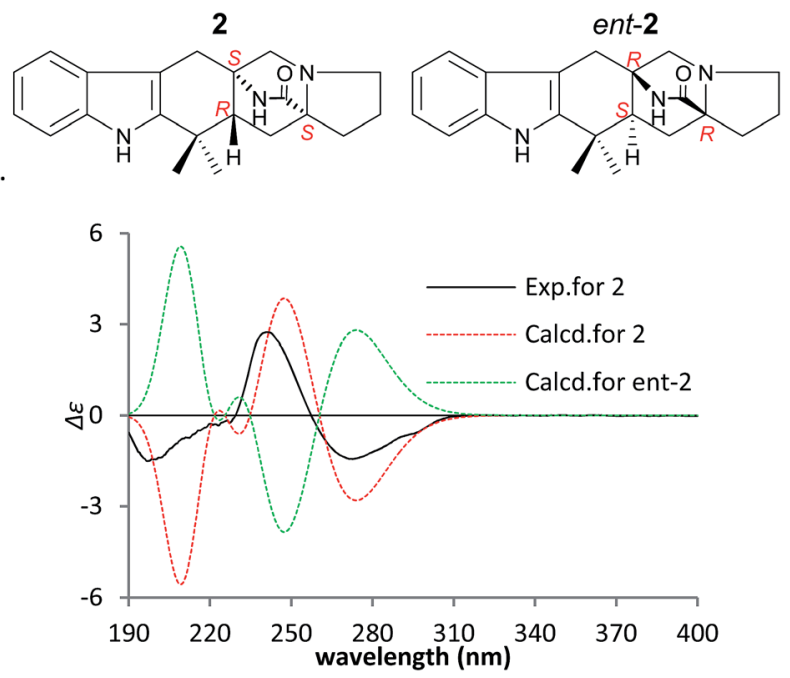

Fig. 6 Measured and calculated ECD spectra of 2 and its enantiomer in $\mathrm{MeOH}$.

evident in the CD spectrum of $\mathbf{3}$. This indicates that 3 is a racemic mixture of $( \pm)$-premalbrancheamide. According to the HPLC analysis of compound 3 on a CHIRALPAK IE column with $65 \%$ $\mathrm{MeOH}$, the (+)-premalbrancheamide content was about $56 \%$, and the (-)-premalbrancheamide content was about $44 \%$ (Fig. 8). The racemic mixture was not separated because we only had a small quantity of 3.

The $\mathrm{MeOH}$ extracts from the mutant $\mathrm{AD}-2-1$ and parent G59 strains were analyzed by HPLC with a photodiode array detector and HPLC-ESI-MS using 1-3 as reference standards. The retention times and the UV and MS spectra (Fig. S2 and S3 in the ESI $\dagger$ ) showed that 1-3 were only present in the mutant extract and not in the parent extract. This is evidence that 1-3 are produced in mutant AD-2-1 following activation of biosynthetic pathways that are silent in the parent G59 strain and subsequently activated by the DES mutagenesis process in the mutant.
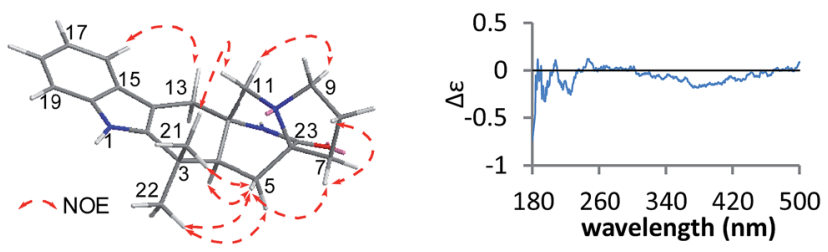

Fig. 7 Key NOE data and the CD spectrum for 3. 


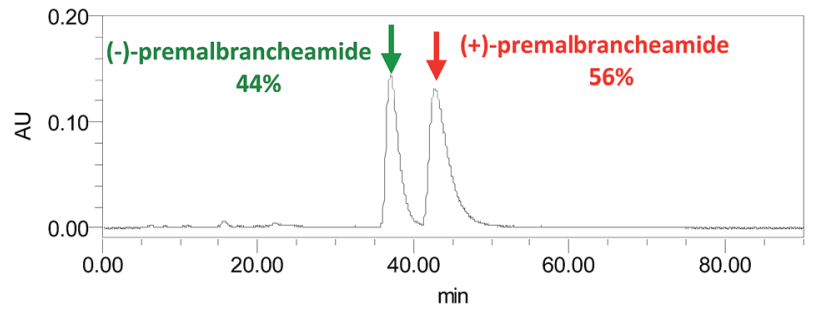

Fig. 8 The HPLC chromatograph of 3 on a CHIRALPAK IE column with $65 \% \mathrm{MeOH}$.

As reported in our previous work, ${ }^{12} 1$ and 2 were both intermediates in plausible biosynthetic pathways for penicimutamides A-C. Plausible biosynthetic pathways for 3 have been reported in earlier studies. ${ }^{22,23}(+)$-Premalbrancheamide was detected in one study, ${ }^{22}$ and was subsequently isolated from the fermentation product of Malbranchea aurantiaca. ${ }^{24}$ (-)-Premalbrancheamide was isolated for the first time in the present study.

To evaluate the inhibitory effect on human cancer cell lines, 1-3 and 5-fluorouracil were tested against human K562, HL-60, HeLa and BGC-823 cell lines at $100 \mu \mathrm{g} \mathrm{mL} \mathrm{m}^{-1}$ by the MTT assay. Compounds 1-3 only showed weak inhibition of the above four cell lines with inhibition rates ranging from $2 \%$ to $27 \%$.

\section{Conclusions}

In our previous work, three rare carbamate-containing alkaloids, penicimutamides $\mathrm{A}-\mathrm{C}$, were isolated from the DES mutant AD-2-1 obtained from the marine-derived fungus Penicillium purpurogenum $\mathrm{G} 59$, and plausible biosynthetic pathways from the precursor deoxybrevianamide E were reported. ${ }^{12}$ In the present work, two new prenylated indole alkaloids, penicimutamides $\mathrm{D}-\mathrm{E}$, which might be intermediates in the biosynthesis of penicimutamides $\mathrm{A}-\mathrm{C}$, were isolated from the mutant AD-2-1. The discovery of penicimutamides A-E from the mutant AD-2-1 strain demonstrates the effectiveness of our previously reported DES mutagenesis strategy ${ }^{19}$ for obtaining new bioactive compounds from silenced fungal pathways. The present work confirms the proposed biosynthetic pathway of penicimutamides A-C.

\section{Conflicts of interest}

The authors declare no conflict interest.

\section{Acknowledgements}

This work was supported by the grants from the NSFC (81573300, 30973631), NHTRDP (2013AA092901, 2007AA09Z411), NSTMP (2009ZX09301-002, 2012ZX09301-003) and AMMS (2008), China.

\section{References}

1 S.-M. Li, Nat. Prod. Rep., 2010, 27, 57.
2 (a) A. J. Birch and J. J. Wright, J. Chem. Soc., Chem. Commun., 1969, 644; (b) A. J. Birch and J. J. Wright, Tetrahedron, 1970, 26, 2329; (c) A. J. Birch and R. A. Russell, Tetrahedron, 1972, 28, 2999.

3 (a) H. Kato, T. Yoshida, T. Tokue, Y. Nojiri, H. Hirota, T. Ohta, R. M. Williams and S. Tsukamoto, Angew. Chem., Int. Ed., 2007, 46, 2254; (b) S. Tsukamoto, H. Umaoka, K. Yoshikawa, T. Ikeda and H. Hirota, J. Nat. Prod., 2010, 73, 1438; (c) S. Tsukamoto, H. Kato, M. Samizo, Y. Nojiri, H. Onuki, H. Hirota and T. Ohta, J. Nat. Prod., 2008, 71, 2064.

4 J. Qian-Cutrone, S. Huang, Y.-Z. Shu, D. Vyas, C. Fairchild, A. Menendez, K. Krampitz, R. Dalterio, S. E. Klohr and Q. Gao, J. Am. Chem. Soc., 2002, 124, 14556.

5 (a) T. J. Greshock, A. W. Grubbs, P. Jiao, D. T. Wicklow, J. B. Gloer and R. M. Williams, Angew. Chem., Int. Ed., 2008, 47, 3573; (b) S. Tsukamoto, T. Kawabata, H. Kato, T. J. Greshock, H. Hirota, T. Ohta and R. M. Williams, Org. Lett., 2009, 11, 1297.

6 (a) M. Yamazaki and E. Okuyama, Tetrahedron Lett., 1981, 22, 135; (b) S. E. Blanchflower, R. M. Banks, J. R. Everett, B. R. Manger and C. J. Reading, Antibiotics, 1991, 44, 492; (c) S. E. Blanchflower, R. M. Banks, J. R. Everett and C. J. Reading, Antibiotics, 1993, 46, 1355.

7 (a) S. Martínez-Luis, R. Rodríguez, L. Acevedo, M. C. González, A. Lira-Rocha and R. Mata, Tetrahedron, 2006, 62, 1817; (b) M. Figueroa, M. D. C. González and R. Mata, Nat. Prod. Res., 2008, 22, 709; (c) K. R. Watts, S. T. Loveridge, K. Tenney, J. Media, F. A. Valeriote and P. Crews, J. Org. Chem., 2011, 76, 6201; (d) Y. Ding, T. J. Greshock, K. A. Miller, D. H. Sherman and R. M. Williams, Org. Lett., 2008, 10, 4863.

8 (a) J. Polonsky, M.-A. Merrien, T. Prangé and C. Pascard, J. Chem. Soc., Chem. Commun., 1980, 13, 601; (b) T. Prangé, M.-A. Billion, M. Vuilhorgne, C. Pascard and J. Poponsky, Tetrahedron Lett., 1981, 22, 1977.

9 (a) R. M. Williams, T. Glinka and E. Kwast, J. Am. Chem. Soc., 1988, 110, 5927; (b) R. M. Williams, T. Glinka, E. Kwast, H. Coffman and J. K. Stille, J. Am. Chem. Soc., 1990, 112, 808; (c) C. Escolano, Angew. Chem., Int. Ed., 2005, 44, 7670; (d) F. C. Frebault and N. S. Simpkins, Tetrahedron, 2010, 66, 6585 .

10 (a) T. J. Greshock and R. M. Williams, Org. Lett., 2007, 9, 4255; (b) R. M. Williams, J. F. Sanz-Cervera, F. Sancenón, J. A. Marco and K. M. Halligan, Bioorg. Med. Chem., 1998, 6, 1233; (c) T. J. Greshock, A. W. Grubbs and R. M. Williams, Tetrahedron, 2007, 63, 6124.

11 (a) R. M. Williams, E. Kwast, H. Coffman and T. Glinka, J. Am. Chem. Soc., 1989, 111, 3046; (b) L. R. Domingo, R. J. Zaragozá and R. M. Williams, J. Org. Chem., 2003, 68, 2895; (c) J. D. Sunderhaus, D. H. Sherman and R. M. Williams, Isr. J. Chem., 2011, 51, 442; (d) J. M. Finefield, H. Kato, T. J. Greshock, D. H. Sherman, S. Tsukamoto and R. M. Williams, Org. Lett., 2011, 13, 3082; (e) H. Kato, T. Hakahara, K. Sugimoto, K. Matsuo, I. Kagiyama, J. C. Frisvad, D. H. Sherman, R. M. Williams and S. Tsukamoto, Org. Lett., 2015, 17, 700. 
12 C.-W. Li, C.-J. Wu, C.-B. Cui, L.-L. Xu, F. Cao and H.-J. Zhu, $R S C A d v .$, 2016, 6, 73383.

13 C.-J. Wu, C.-W. Li and C.-B. Cui, Mar. Drugs, 2014, 12, 1815. 14 H. B. Bode, B. Bethe, R. Hofs and A. Zeeck, ChemBioChem, 2002, 3, 619.

15 R. B. Williams, J. C. Henrikson, A. R. Hoover, A. E. Lee and R. H. Cichewicz, Org. Biomol. Chem., 2008, 6, 1895.

16 A. Marmann, A. H. Aly, W. Lin, B. Wang and P. Proksch, Mar. Drugs, 2014, 12, 1043.

17 (a) Y.-J. Chai, C.-B. Cui, C.-W. Li, C.-J. Wu, C.-K. Tian and W. Hua, Mar. Drugs, 2012, 10, 559; (b) C.-J. Wu, L. Yi, C.-B. Cui, C.-W. Li, N. Wang and X. Han, Mar. Drugs, 2015, 13, 2465; (c) Y. Dong, C.-B. Cui, C.-W. Li, W. Hua, C.-J. Wu, T.-J. Zhu and Q.-Q. Gu, Mar. Drugs, 2014, 12, 4326; (d) N. Wang, C.-B. Cui and C.-W. Li, Arch. Pharmacal Res., 2016, 39, 762; (e) L. Yi, C.-B. Cui, C.-W. Li, J.-X. Peng and Q.-Q. Gu, RSC Adv., 2016, 6, 43975.

18 (a) K. Ochi, S. Okamoto, Y. Tozawa, T. Inaoka, T. Hosaka, J. Xu and K. Kurosawa, Adv. Appl. Microbiol., 2004, 56, 155; (b) K. Ochi, Biosci., Biotechnol., Biochem., 2007, 71, 1373.

19 (a) S.-M. Fang, C.-J. Wu, C.-W. Li and C.-B. Cui, Mar. Drugs, 2014, 12, 1788; (b) S.-M. Fang, C.-B. Cui, C.-W. Li, C.-J. Wu, Z.-J. Zhang, L. Li, X. J. Huang and W. C. Ye, Mar. Drugs,
2012, 10, 1266; (c) M.-W. Xia, C.-B. Cui, C.-W. Li and C.-J. Wu, Mar. Drugs, 2014, 12, 1545; (d) M.-W. Xia, C.-B. Cui, C.-W. Li, C.-J. Wu, J.-X. Peng and D.-H. Li, Mar. Drugs, 2015, 13, 5219.

20 (a) M. J. Frisch, G. W. Trucks and H. B. Schlegel, et al., Gaussian, Inc., Wallingford CT, 2010; (b) T. Bruhn, A. Schaumlöffel, Y. Hemberger, and G. Bringmann, Version 1.61, University of Würzburg, Würzburg, Germany, 2013; (c) T. Bruhn, A. Schaumlöffel, Y. Hemberger and G. Bringmann, Chirality, 2013, 25, 243.

21 The TDDFT ECD calculations for 1 and 2 was performed using the Gaussian 09 software package, Gaussian 09, Revision A.02, Gaussian, Wallingford, CT, USA, 2010, see details in the ESI $\dagger$

22 Y. Ding, T. J. Greshock, K. A. Miller, D. H. Sherman and R. M. Williams, Org. Lett., 2008, 10, 4863.

23 K. R. Watts, S. T. Loveridge, K. Tenney, J. Media, F. A. Valeriote and P. Crews, J. Org. Chem., 2011, 76, 6201.

24 M. Figueroa, M. González-Andrade, A. Sosa-Peinado, A. Madariaga-Mazón, F. Del Río-Portilla, M. Del Carmen González and R. Mata, J. Enzyme Inhib. Med. Chem., 2011, 26, 378 . 